\title{
COMPRESSIVE STRENGTH VARIABILITY OF BROWN COAL FLY ASH GEOPOLYMER CONCRETE
}

\author{
Rahmat Dirgantara ${ }^{1}$, David W. Law ${ }^{2}$, Tom K. Molyneaux ${ }^{3}$

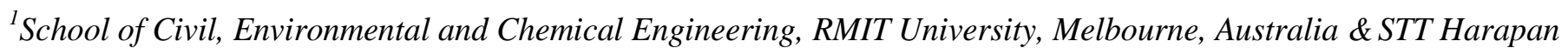 \\ College, Medan, Indonesia \\ ${ }^{2}$ School of Civil, Environmental and Chemical Engineering, RMIT University, Melbourne, Australia \\ ${ }^{3}$ School of Civil, Environmental and Chemical Engineering, RMIT University, Melbourne, Australia
}

\begin{abstract}
The use of Fly Ash (FA) as an alternative binder material to Ordinary Portland Cement (OPC) is well established, with class $F$ FA the most commonly used in the synthesis of this alkali-activated binder at present. ASTM C618 classifies FA as class F produced from anthracite and bituminous and class $C$ from lignite and sub-bituminous coals. In Australia, Victoria FA is produced from lignite known as Brown Coal (BC), but due to the chemical composition cannot categorize as class C. Recent studies have shown the viability of using $100 \%$ BC FA as the binder to create alkali activated geopolymer concrete. A previous study using Victoria BC FA for geopolymer concrete provided strength of more than 40MPa which is comparable to class $F$ geopolymer and OPC specimens. The activation process of geopolymer concrete varies remarkably from PC concrete, due to the activation of the aluminosilicate by high concentration alkali. Therefore, the durability of geopolymer concrete may possibly be different to OPC concrete. This paper reports on a research project investigating compressive strength variability that could, in turn, affect the durability characteristic of the BC FA geopolymer concrete for use in the construction industry.
\end{abstract}

Keywords: fly ash, brown coal, geopolymer concrete, variability, compressive strength

\section{INTRODUCTION}

Environmental concerns have been raised regarding the energy consumption and the emission of $\mathrm{CO}_{2}$ in the production of Portland cement as the main binder material in concrete $[1,2]$. While other concerns have highlighted the use of coal as a primary energy source in the world. The use of coal releases FA as a by-product material, some of which becomes environmental waste [3].

In order to address these environmental issues, the use of waste products such as FA as partial replacement materials for OPC have become well established [1, 4, 5]. These materials give both an environmental benefit, being waste materials and also provide improved performance for the concrete produced, especially in the area of durability.

ASTM C618 [6] defines FA into 2 classes, class F and class C. Class F FA is produced from burning anthracite and bituminous coals, while class C FA is produced from subbituminous coals and lignite. Both have pozzolanic properties, and in addition to that, class C FA also has some cementitious properties. At present only class F FA may be used as a partial replacement material for Portland cement, while class C FA cannot be used as a replacement material for OPC, due to the chemical composition adversely affecting the properties of the concrete produced.

Australia's 2008 recoverable lignite (low-rank coal) also known as BC is estimated to be 37.2 giga tonnes, all of which is located in La Trobe Valley, Victoria [7]. Victoria annually produces more than 500 kilo tonnes of combined
BC FA and bottom ash. There are three sources of BC FA in Victoria, Loy Yang, Hazelwood and Yallourn power station, in the La Trobe valley. Each FA has a unique composition. So far little research has been undertaken on the feasibility of using BC FA as a waste product $[8,9]$. The BC FA is not used a partial replacement material due to the $\mathrm{CaO}$ content and the very high $\mathrm{SO}_{3}$ content. As such there is no commercial use of the material in the construction industry, with the majority of the material being sent to landfill at present.

\subsection{Geopolymer Concrete}

Recent research has shown the feasibility of using class $\mathrm{F}$ FA as $100 \%$ of the binder to create alkali-activated concrete, known as geopolymer concrete [10]. The activation process for geopolymer concretes is due to the activation of the aluminosilicates by high concentration alkali [11] rather than the activation of the FA by the $\mathrm{Ca}(\mathrm{OH})_{2}$ produced by the hydration of the OP cement [12]. To date research has focused on the use of class F FA, which has a high aluminosilicates content, which is required for the activation process. Therefore, if the composition of the aluminosilicates in the class C FA is sufficient it may be feasible to use them to produce geopolymer concrete. The potential demonstrated for class C FA could also be applied to BC FA that is a by-product from the same source. This potential use of BC FA could result in utilization of a widespread industrial by-product from coal burning power stations, which is presently dumped into the environment.

A previous study at RMIT on geopolymer concrete using Loy Yang BC FA as $100 \%$ replacement of OPC 
demonstrated compressive strength comparable to those obtained from OPC concrete [13]. The results were indicative that Loy Yang BC FA geopolymer concrete can produce compressive strengths acceptable for use in the construction industry.

Good performance service and durability is a major factor for success of concrete as a construction material [14]. Durability of concrete is the ability to resist weathering action, chemical attack, abrasion, or any process of deterioration as a result of a variety of physical and chemical processes. Further investigation is required to determine the mechanical properties and durability characteristics of the geopolymer concrete prior to use in the construction industry.

The paper reports an ongoing investigation of compressive strength variability that could affected the durability characteristic of Loy Yang, Victoria BC FA geopolymer concrete.

\section{MATERIALS AND METHODS}

\subsection{Materials}

The FA used in this study came from Loy Yang Power Station in the La Trobe Valley, Victoria, Australia. Table 1 shows chemical composition of the BC FA supplied and chemical composition from a study previously reported in 1993 [15].

Table 1: Chemical Composition of Loy Yang BC FA

\begin{tabular}{|l|l|l|}
\hline $\begin{array}{l}\text { Oxide } \\
(\%)\end{array}$ & Current Study & Ref [15] \\
\hline $\mathrm{SiO}_{2}$ & 47.52 & 60.4 \\
\hline $\mathrm{Al}_{2} \mathrm{O}_{3}$ & 17.29 & 13.3 \\
\hline $\mathrm{Fe}_{2} \mathrm{O}_{3}$ & 5.98 & 8.5 \\
\hline $\mathrm{CaO}$ & 2.25 & 1.0 \\
\hline $\mathrm{MgO}$ & 4.63 & 2.2 \\
\hline $\mathrm{K}_{2} \mathrm{O}$ & 0.50 & 1.2 \\
\hline $\mathrm{Na}_{2} \mathrm{O}$ & 6.26 & 2.1 \\
\hline $\mathrm{TiO}_{2}$ & 1.26 & 1.7 \\
\hline $\mathrm{P}_{2} \mathrm{O}_{5}$ & 0.74 & \\
\hline $\mathrm{SO}_{3}$ & 13.03 & 3.4 \\
\hline $\mathrm{Cl}$ & & $<0.1$ \\
\hline $\mathrm{Cl}{ }_{2} \mathrm{O}$ & 0.44 & \\
\hline $\mathrm{Mn}_{2} \mathrm{O}$ & 0.10 & \\
\hline $\mathrm{LOI}$ & & 7.6 \\
\hline
\end{tabular}

A $15 \mathrm{M}$ sodium hydroxide solution (with composition of $37.5 \% \mathrm{NaOH}$ and $62.5 \%$ water) was used together with sodium silicate $\left(\mathrm{Na}_{2} \mathrm{SiO}_{3}\right)$ with a 2.00 ratio liquid sodium silicate $\left(\mathrm{Na}_{2} \mathrm{O}=14.7 \%, \mathrm{SiO}_{2}=29.4 \%\right.$ and $55.90 \%$ water $)$ of $1.52 \mathrm{~g} / \mathrm{cc}$ density.

\subsection{Mix Design}

The mix design used in this study was based on the best mix from an earlier pilot study of geopolymer mortar [16]. Table
2 shows the mix proportions and mass ratios of mortar specimen from the pilot study.

A portion of fine aggregate (sand) was substituted by a combination of sand and aggregates. The aggregates used for the mix was a combination of $43 \%$ of sand, $38 \%$ of $10 \mathrm{~mm}$ aggregate and $19 \%$ of $7 \mathrm{~mm}$ aggregate (Table 3 ). Those percentages of combined aggregates were adopted from previous research at RMIT in the development of Class F FA geopolymer concrete with the same source of aggregates [17]. The fine aggregate was uncrushed sand and the coarse aggregates were crushed basalt aggregate. The aggregate moisture condition was oven dried aggregates.

Table 2: Mortar Mix Proportion and Mass Ratio

\begin{tabular}{|l|l|l|l|}
\hline \multicolumn{4}{|l|}{ Mass Proportion $(\mathrm{kg})$} \\
\hline $\mathrm{BC}$ FA & Sand & $\mathrm{Na}_{2} \mathrm{SiO}_{3}$ & $\mathrm{NaOH}$ \\
\hline 0.279 & 1.677 & 0.363 & 0.021 \\
\hline Mass Ratio & Liquid/Solid & FA wt $\%$ \\
\hline $\mathrm{SiO}_{2} / \mathrm{Na}_{2} \mathrm{O}$ & 0.102 & 11.94 \\
\hline 3.11 &
\end{tabular}

Table 3: BC FA Geopolymer Concrete Mix Proportion

\begin{tabular}{|c|c|c|c|c|c|}
\hline \multicolumn{6}{|c|}{ Mass (kg) } \\
\hline \multirow{2}{*}{ BC FA } & \multicolumn{3}{|c|}{ Aggregates } & \multirow{2}{*}{$\mathrm{Na}_{2} \mathrm{SiO}$} & \multirow{2}{*}{$\begin{array}{l}\mathrm{NaO} \\
\mathrm{H}\end{array}$} \\
\hline & Sand & $7-\mathrm{mm}$ & $10-\mathrm{mm}$ & & \\
\hline 0.279 & 0.721 & 0.319 & 0.637 & 0.363 & 0.021 \\
\hline
\end{tabular}

\subsection{Preparation of BC FA Geopolymer Concrete}

The casting procedure was adopted from the previous geopolymer study at RMIT [17]. The BC FA geopolymer concrete mixing was performed using a 25-litre mixer. Directly after mixing the concrete was placed in $100 \mathrm{x} 100 \mathrm{x}$ $100 \mathrm{~mm}$ cubic molds. The specimens were compacted with two-layer placing and tamping, and placed on a vibration table for 30 seconds. The specimens were left for 24 hours at room temperature and then covered to prevent moisture loss and put in the oven pre-heated at $120^{\circ} \mathrm{C}$ for 10 hours. The specimens were left to cool at room temperature before being de-molded. The specimens were kept at room temperature prior to testing. Elevated curing has been shown to assist the chemical reactions that occurs in geopolymer concrete $[12,18]$. An earlier study validated a curing temperature of $120^{\circ} \mathrm{C}$ as suitable for La Trobe Valley BC FA [19]. A curing temperature of $120^{\circ} \mathrm{C}$ resulted in a significantly higher compressive strength for BC FA mortar specimens than a curing temperature of $80^{\circ} \mathrm{C}$.

Table 4: Group of Casting, Mass and Volume

\begin{tabular}{|l|l|l|}
\hline Group & Mass $(\mathrm{kg})$ & Volume (litre) \\
\hline 1 & 26.881 & 11 \\
\hline 2 & 53.884 & 22.05 \\
\hline 3 & 61.581 & 25.2 \\
\hline 4 & 35.922 & 14.7 \\
\hline 5 & 34.488 & 15.75 \\
\hline 6 & 29.569 & 12.1 \\
\hline
\end{tabular}


A total of 6 mixes were cast. These specimens were intended for both compressive strength and durability tests and as such were of different volumes (mass). Table 4 lists the total mass and volume per mix. Each mix was produced from the same batch of BC FA supplied from Loy Yang power station directly from the precipitator units with no pre-treatment. Each mix consisted of $3 \times 100 \mathrm{~mm}^{3}$ cubes for compressive strength tests at 28 days and a range of different size and shape specimens for durability tests.

\section{COMPRESSIVE STRENGTH RESULTS}

Compressive strength measurements were performed on a Universal Testing Machine and MTS machine in accordance with BS EN 12390-3. Three cubes were tested for each data point.

A total of 6 groups of samples were tested for compressive strength, Table 5. Group 1 was tested at 7, 28 and 91 days, groups 2-6 were tested at 28 days.

Table 5: BC FA Geopolymer Compressive Strength Results

\begin{tabular}{|l|l|l|l|}
\hline \multirow{2}{*}{ Group } & \multicolumn{3}{|l|}{$\begin{array}{l}\text { Compressive Strength - MPa } \\
\text { Mean(SD) }\end{array}$} \\
\cline { 2 - 4 } & 7days & 28days & 91days \\
\hline 1 & $44.95(1.98)$ & $43.81(4.31)$ & $42.62(6.25)$ \\
\hline 2 & & $29.38(6.62)$ & \\
\hline 3 & & $23.76(2.73)$ & \\
\hline 4 & & $7.21(2.35)$ & \\
\hline 5 & & $31.41(7.72)$ & \\
\hline 6 & & $13.29(4.43)$ & \\
\hline
\end{tabular}

\section{DISCUSSION AND CONCLUSION}

The compressive strength results (Table 5) show a large range in strength, from $43.81 \mathrm{MPa}$ (group 1) to $7.21 \mathrm{MPa}$ (group 4) at 28 days. The results indicate a wide variation in the quality of the material. It is hypothesized that this variation may be due to BC FA being supplied as a raw material, with no pretreatment and refining, as undertaken for commercial Class F FA. A significant variation in the chemical composition was observed compared to that reported by other authors [15] despite the materials being from the same source, Table 1.

Table 6: Composition Variation of Loy Yang BC FA

\begin{tabular}{|c|c|c|c|c|c|}
\hline \multirow{2}{*}{$\begin{array}{l}\text { Oxide } \\
(\%)\end{array}$} & \multicolumn{5}{|c|}{ Sample } \\
\hline & $\mathrm{A}$ & B & $\mathrm{C}$ & $\mathrm{D}$ & $\mathrm{E}$ \\
\hline $\mathrm{SiO}_{2}$ & 51.92 & 49.66 & 54.16 & 52.96 & 67.53 \\
\hline $\mathrm{Al}_{2} \mathrm{O}_{3}$ & 12.42 & 13.54 & 13.00 & 12.69 & 8.53 \\
\hline $\mathrm{Fe}_{2} \mathrm{O}_{3}$ & 6.84 & 7.05 & 7.01 & 7.06 & 4.54 \\
\hline $\mathrm{CaO}$ & 2.47 & 2.57 & 2.34 & 2.35 & 1.23 \\
\hline $\mathrm{MgO}$ & 4.13 & 4.34 & 3.64 & 4.06 & 2.28 \\
\hline $\mathrm{K}_{2} \mathrm{O}$ & 0.51 & 0.46 & 0.48 & 0.48 & 0.51 \\
\hline $\mathrm{Na}_{2} \mathrm{O}$ & 5.24 & 5.29 & 4.75 & 5.50 & 3.63 \\
\hline $\mathrm{TiO}_{2}$ & 1.23 & 1.17 & 1.27 & 1.21 & 1.15 \\
\hline $\mathrm{P}_{2} \mathrm{O}_{5}$ & 0.71 & 0.58 & 0.49 & 0.47 & 0.82 \\
\hline $\mathrm{SO}_{3}$ & 13.86 & 14.73 & 12.43 & 12.42 & 9.09 \\
\hline $\mathrm{Cl}_{2} \mathrm{O}$ & 0.54 & 0.51 & 0.38 & 0.73 & 0.56 \\
\hline
\end{tabular}

\begin{tabular}{|l|l|l|l|l|l|}
\hline $\mathrm{Mn}_{2} \mathrm{O}$ & 0.15 & 0.09 & 0.08 & 0.10 & 0.14 \\
\hline
\end{tabular}

Therefore, additional chemical analysis was done to determine the inherent variation in the material. Table 6 shows chemical composition variation of 5 additional samples taken from the same batch as used in the compressive strength tests reported in Table 5. The data shows significant variations with the $\mathrm{SiO}_{2}$ content varying from $47.52 \%$ (current study; Table 1) to $67.53 \%$ (Table 6, Sample E), the $\mathrm{Al}_{2} \mathrm{O}_{3}$ content varying from $17.29 \%$ (current study, Table 1) to $8.53 \%$ (Table 6, Sample E) and the total $\mathrm{SiO}_{2}+\mathrm{Al}_{2} \mathrm{O}_{3}$ content varying from $76.06 \%$ (Table 6, Sample E) to $63.2 \%$ (Table 6, Sample B).

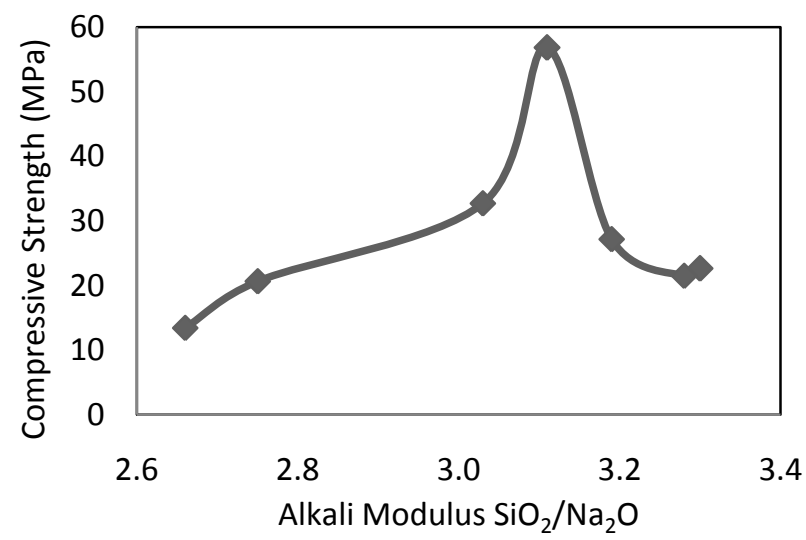

Fig. 1 Strength vs Alkali Modulus $\left(\mathrm{SiO}_{2} / \mathrm{Na}_{2} \mathrm{O}\right)$ observed in earlier studies [20].

The activator modulus (Ms) is the mass ratio of the $\mathrm{SiO}_{2}$ to $\mathrm{Na}_{2} \mathrm{O}$ in the alkaline activator $\left(\mathrm{NaOH}\right.$ and $\mathrm{Na}_{2} \mathrm{SiO}_{3}$ solutions). The modified activator modulus (Msm) is calculated to include the silicon dioxide $\left(\mathrm{SiO}_{2}\right)$ and sodium oxide $\left(\mathrm{Na}_{2} \mathrm{O}\right)$ content from the BC FA. Earlier studies has indicated the important role of alkali modulus $\mathrm{SiO}_{2} / \mathrm{Na}_{2} \mathrm{O}$ in determining compressive strength of geopolymer mortar $[16,20]$. Figure 1 shows the influence of the alkali modulus $\left(\mathrm{SiO}_{2} / \mathrm{Na}_{2} \mathrm{O}\right)$ on the 7days strength of the Loy Yang BC FA geopolymer mortar [20]. The alkali modulus of the graph is a modified activator modulus (Msm). It shows the small range of mix compositions for which compressive strength above $40 \mathrm{MPa}$ can be achieved. The optimum compressive strength of $56 \mathrm{MPa}$ was obtained with an alkali modulus 3.11 .

Table 7: Alkali Modulus of different chemical composition

\begin{tabular}{|l|l|l|}
\hline \multirow{2}{*}{ Sample } & \multicolumn{2}{|l|}{ Activator Modulus } \\
\cline { 2 - 3 } & Ms & Msm \\
\hline Ref [13] & 1.795 & 3.112 \\
\hline A & 1.795 & 3.398 \\
\hline B & 1.795 & 3.306 \\
\hline C & 1.795 & 3.548 \\
\hline D & 1.795 & 3.404 \\
\hline E & 1.795 & 4.245 \\
\hline
\end{tabular}

Using the chemical composition variation of Loy Yang BC FA (Table 6), the Ms and Msm were calculated from the mix proportion BC FA geopolymer concrete (Table 2 and 
3). Table 7 illustrates how the inherent variations in the material gave substantial differences in alkali modulus Msm. The initial trial study sample [13] had the lowest Msm of all the samples, while all the other samples have higher values. The higher values of $\mathrm{Msm}$ are in the region corresponding to compressive strengths for a mortar of less than $30 \mathrm{MPa}$ (Figure 1), correlating with the values actually observed for the concretes.

These results indicate that the compressive strength of the concrete is highly dependent on the chemical composition (and hence Msm) of the BC FA. As such the quality of the BC FA used in the manufacture is critical to the quality of the concrete and that refining of the BC FA may be necessary prior to adoption as a geopolymer concrete material.

It is further hypothesized that the increase in volume of the sample sizes has contributed to the variations in strength observed. Table 4 shows the smallest mix, group 1, provided the highest compressive strength of 42-44MPa. An initial trial study on small batch Loy Yang BC FA geopolymer concrete gave results ranging from $40-60 \mathrm{MPa}$, Table 8 [13]. Mix 1 used saturated surface dry aggregates, and mix 2 used oven dried aggregates. Both mixes in Table 8 had the same mass $(26.881 \mathrm{~kg})$ and volume (11 litres), similar to group 1 in Table 4. The results both show higher compressive strengths are achieved for lower volumes of mix.

Table 8: BC FA Geopolymer Compressive Strength Results obtained in earlier study [13].

\begin{tabular}{|l|l|l|l|}
\hline BC FA & \multicolumn{4}{|l|}{ Compressive Strength - MPa } \\
GC & Mean(SD) \\
\hline \multirow{2}{*}{ Mix 1 } & 3days & 7days & 28days \\
\cline { 2 - 4 } & $45.98(1.65)$ & 43.60(4.26) & 40.59(8.00) \\
\hline \multirow{2}{*}{ Mix 2 } & 7 days & 56days & 91days \\
\cline { 2 - 4 } & $59.59(3.49)$ & $52.08(3.88)$ & $60.38(0.46)$ \\
\hline
\end{tabular}

Mixing of the material is an important factor in enabling efficient dissolution of the FA particles. The increased volumes may also have led to inefficiencies in the mixing, which further contribute to the variations in strength.

\section{CONCLUDING REMARKS}

The sample of BC FA geopolymer concrete of this paper were intended to use for durability testing of Loy Yang BC FA geopolymer concrete. However the compressive strength results demonstrated significant variations. Analysis of the chemical compositions of the BC FA observed a wide range of silicate and aluminate concentrations, which is attributed as the primary reason for this variation. The lack of pretreatment of the BC FA, which is an untreated waste material, is hypothesized as the cause of the variation observed. The results indicate that further treatment of the BC FA may be necessary prior to adoption as a geopolymer concrete material. Durability testing of the BC FA geopolymer concrete such as air and water permeability test, carbonation, salt ponding test, rapid chloride permeability test will be continued once this issue has been addressed.

\section{ACKNOWLEDGEMENTS}

Chemical analysis and imaging are performed using the facilities, and the scientific and technical assistance of the Australian Microscopy \& Microanalysis Research Facility at the RMIT Microscopy \& Microanalysis Facility, at RMIT University.

The authors would like to thank AGL Loy Yang Power Station for providing the Brown Coal Fly Ash and PQ Australia Pty Ltd for providing the Sodium Silicate.

\section{REFERENCES}

[1]. Berry M, Cross D, Stephens J. Changing the Environment: An Alternative "Green" Concrete Produced without Portland Cement. 2009 World of Coal Ash (WOCA) Conference. Lexington, KY, USA 2009.

[2]. Davidovits J. Global Warming Impact on the Cement and Aggregates Industries. World Resource Review. 1994;6(2):263-78.

[3]. Naik TR, Singh SS. Fly Ash Generation and Utilization - An Overview. 1993.

[4]. Oscar E. Coal Fly Ash: a retrospective and future look. Fuel. 1999;78(2):133-6.

[5]. Fansuri H, Prasetyoko D, Zhang Z, Zhang D. The effect of sodium silicate and sodium hydroxide on the strength of aggregates made from coal fly ash using the geopolymerisation method. Asia-Pacific Journal of Chemical Engineering. 2012;7(1):73-9.

[6]. ASTM. ASTM C618-12. Standard Specification for Coal Fly Ash and Raw or Calcined Natural Pozzolan for Use in Concrete. West Conshohocken, US.: ASTM International; 2012.

[7]. Geoscience Australia, ABARE. Australian Energy Resource Assessment. Canberra: Commonwealth of Australia (Geoscience Australia); 2010.

[8]. Bankowski P, Zou L, Hodges R. Using inorganic polymer to reduce leach rates of metals from brown coal fly ash. Minerals Engineering. 2004;17(2):159-66.

[9]. Škvára F, Kopecký L, Šmilauer V, Bittnar Z. Material and structural characterization of alkali activated lowcalcium brown coal fly ash. Journal of Hazardous Materials. 2009; 168(2-3):711-20.

[10]. Berry M, Stephens J, Cross D. Performance of $100 \%$ Fly Ash Concrete with Recycled Glass Aggregate. ACI Materials Journal. 2011;108(4):378-84.

[11]. Davidovits J. Geopolymers: Man-Made Rock Geosynthesis and the Resulting Development of Very Early High Strength Cement. Journal of Materials Education. 1994;16(2/3):48.

[12]. Neville A, M. Properties of Concrete. 5th ed. England: Pearson Education Limited; 2011.

[13]. Dirgantara R, Law D, Molyneaux T. Brown Coal Fly Ash Geopolymer Concrete. In: Vinh Dao, Dux P, editors. Concrete 2013. Gold Coast 2013.

[14]. Papadakis VG, Vayenas CG, Fardis MN. Physical and Chemical Characteristics Affecting the Durability of Concrete. ACI Materials Journal. 1991;8(2):11.

[15]. Macphee DE, Black CJ, Taylor AH. Cements Incorporating Brown Coal Fly Ash from The Latrobe Valley 
Region of Victoria, Australia. Cement and Concrete Research. 1993;23(3):507-17.

[16]. Dirgantara R, Law D, Molyneaux T, Kong D. Brown coal fly ash geopolymer mortar. In: Bijan Samali MMA, Chongmin Song, editor. ACMSM 22. Sydney: CRC Press; 2013.

[17]. Adam A. Strength and durability properties of alkali activated slag and fly ash-based geopolymer concrete. Melbourne, RMIT University; 2009.

[18]. Lloyd NA, Rangan BV. Geopolymer Concrete with Fly Ash. Second International Conference on Sustainable Construction Materials and Technologies. Universita Politecnica delle Marche, Ancona, Italy 2010.

[19]. Law DW, Molyneaux TM, Wardhono A, Dirgantara R, Kong D. The Use Brown Coal Fly Ash To Make Geopolymer Concrete. ACCTA 2013. Johannesburg 2013. p. 8.

[20]. Law D, Molyneaux T, Dirgantara R. Properties of Brown Coal Fly Ash Geopolymer Mortars. In: Vinh Dao, Dux P, editors. Concrete 2013. Gold Coast 2013

\section{BIOGRAPHIES}

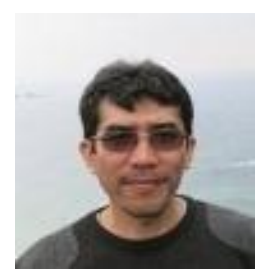

Rahmat Dirgantara has received his master of engineering science from the University of Melbourne, Australia. Working as a lecturer in Civil Department STT Harapan College, Medan, Indonesia. Currently doing PhD at RMIT University. His research interest areas are in structural design and material.

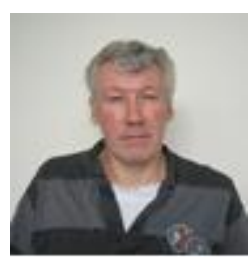

Dr Law is currently a lecturer at RMIT University. His research interests are in the durability and performance of reinforced concrete structures. Particular areas of research are in electrochemical monitoring and protection, the use of sustainable materials and material properties of concrete.

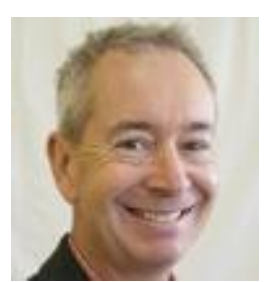

Associate Professor Tom Molyneaux is Deputy Head - Learning \& Teaching at School of Civil, Environmental and Chemical Engineering, RMIT University. He has a strong background in masonry, impact dynamics and concrete durability, NDT, instrumentation, data acquisition and non-linear numerical modelling. He has a particular focus on project-based learning and the innovative use of IT. 